\title{
Synthesis of $\mathrm{MgSiN}_{2}$ Powders from the Mg-Si System
}

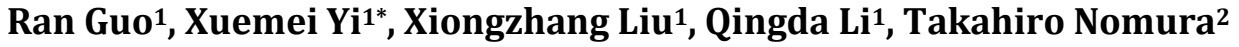 \\ ${ }^{1}$ College of Mechanical and Electronic Engineering, Northwest A \& F University, Shaanxi, China \\ ${ }^{2}$ Center for Advanced Research of Energy and Materials, Hokkaido University, Sapporo, Japan \\ Email: ^xuemei_yi@nwsuaf.edu.cn
}

How to cite this paper: Guo, R., Yi, X.M., Liu, X.Z., Li, Q.D. and Nomura, T. (2018) Synthesis of $\mathrm{MgSiN}_{2}$ Powders from the MgSi System. Journal of Materials Science and Chemical Engineering, 6, 68-79. https://doi.org/10.4236/msce.2018.61008

Received: December 25, 2017

Accepted: January 26, 2018

Published: January 29, 2018

Copyright () 2018 by authors and Scientific Research Publishing Inc. This work is licensed under the Creative Commons Attribution International License (CC BY 4.0).

http://creativecommons.org/licenses/by/4.0/

(c) (i) Open Access

\begin{abstract}
Magnesium silicon nitride $\left(\mathrm{MgSiN}_{2}\right)$ was synthesized without any additives under a nitrogen gas flow $(200 \mathrm{~mL} / \mathrm{min})$ using a nitriding method. The effects of temperature and holding time on its purity and morphology were investigated. A single-phase $\mathrm{MgSiN}_{2}$ powder was obtained at $1350^{\circ} \mathrm{C}$ for $1 \mathrm{~h}$ and $1250^{\circ} \mathrm{C}$ for $11 \mathrm{~h}$. However, the decomposition of $\mathrm{MgSiN}_{2}$ occurred at $1450^{\circ} \mathrm{C}$, suggesting that the optimum temperature for the preparation of $\mathrm{MgSiN}_{2}$ from $\mathrm{Mg}$-Si system was $1350^{\circ} \mathrm{C}$. The phase purity, morphology, size of the product and elemental composition of the samples were detected by X-ray diffraction (XRD), scanning electron microscopy (SEM) and energy spectrometer (EDS), respectively. The evaporation of $\mathrm{Mg}$ and $\mathrm{Si}$ resulted in the formation of many voids in the blocky product. The temperature gradient promotes the growth of $\mathrm{MgSiN}_{2}$ on the surface of massive products along the tip. The concentration gradient of $\mathrm{Mg}$ and Si vapors in the void resulted in the columnar growth of $\mathrm{MgSiN}_{2}$.
\end{abstract}

\section{Keywords}

Nitride Materials, Crystal Growth, X-Ray Diffraction, Mg-Si System

\section{Introduction}

In recent years, ternary nitrides have been widely investigated due to their higher functionality than binary nitrides. $\beta$-SiAlON, $\mathrm{Si}_{3} \mathrm{~N}_{4}$, and AlN all exhibit excellent thermal performances [1]-[7]. The crystal structure of $\mathrm{MgSiN}_{2}$ belongs to the orthorhombic system similar to AlN; however, the mechanical properties of $\mathrm{MgSiN}_{2}$ are superior to those of AlN. Thus, $\mathrm{MgSiN}_{2}$ has attracted extensive attention owing to its high fracture toughness $\left(3 \mathrm{MPa} \cdot \mathrm{m}^{1 / 2}\right)$, high stress intensity (280 MPa), high hardness (20 GPa), high-temperature electrical insulation, 
high-temperature oxidation resistance (up to $920^{\circ} \mathrm{C}$ ), excellent thermal conductivity, etc. [8]-[13]. In view of its theoretical thermal conductivity value of up to $75 \mathrm{~W} / \mathrm{m} \cdot \mathrm{K}, \mathrm{MgSiN}_{2}$ should replace the AlN material as a new generation of ceramic materials with high thermal conductivity [14]. It can also be used as substrate material, packaging material, fluorescent material, for sintering aid of non-oxide ceramics with high thermal conductivity, and as growth additive in the combustion synthesis of $\beta-\mathrm{Si}_{3} \mathrm{~N}_{4}$ rod crystals. Therefore, it is considered a very promising engineering and functional ceramic material [15]-[25].

In the past few decades, the preparation of $\mathrm{MgSiN}_{2}$ using different methods and raw materials has been widely studied. Uchlda et al. [26] obtained single-phase $\mathrm{MgSiN}_{2}$ by nitridation of $\mathrm{Mg}_{2} \mathrm{Si}$ at $1400^{\circ} \mathrm{C}$ for $1 \mathrm{~h}$. Bruls et al. [27] used $\mathrm{Mg}_{3} \mathrm{~N}_{2} / \mathrm{Si}_{3} \mathrm{~N}_{4}$ as starting mixture to obtain $\mathrm{MgSiN}_{2}$ with oxygen content of only $0.1 \pm 0.1 \mathrm{wt} \%$. $\mathrm{Mg}$ and $\mathrm{Si}$ have also been used as raw materials to synthesize $\mathrm{MgSiN}_{2}$ at $1250^{\circ} \mathrm{C}$ for $16 \mathrm{~h}$; however, no single-phase products were obtained. Lences et al. [28] synthesized $\mathrm{MgSiN}_{2}$ by direct nitridation of complex mixtures consisting of $\mathrm{Mg} / \mathrm{Si} / \mathrm{Si}_{3} \mathrm{~N}_{4} / \mathrm{Mg}_{2} \mathrm{Si}$, and reported the thermal analysis, phase composition, and characterization of the resulting $\mathrm{MgSiN}_{2}$ powders. Khajelakzay et al. [9] prepared $\mathrm{MgSiN}_{2}$ nanopowders by mechanical alloying and heat treatment in two steps, using $\mathrm{Mg} / \mathrm{Si}$ as starting mixtures and adding a small amount of stearic acid. Yang et al. [29] synthesized single-phase $\mathrm{MgSiN}_{2}$ powders starting from $\mathrm{Mg} / \mathrm{Si}_{3} \mathrm{~N}_{4}$ by combustion synthesis, followed by acid washing. The preparation of $\mathrm{MgSiN}_{2}$ by carbothermal reduction was also reported [30]. The synthesis of $\mathrm{MgSiN}_{2}$ by a solvothermal method used $\mathrm{SiCl}_{4}, \mathrm{~N}_{2} \mathrm{H}_{4} \cdot \mathrm{HCl}$, and $\mathrm{Mg}$ as starting materials [10]. The use of $\mathrm{SiO}_{2}$ and $\mathrm{Mg}_{3} \mathrm{~N}_{2}$ as reactants was described to synthesize $\mathrm{MgSiN}_{2}$ by a solid-state metathesis route [31]. However, no singlephase $\mathrm{MgSiN}_{2}$ has yet been prepared by direct nitridation at low temperatures $\left(1250^{\circ} \mathrm{C}\right)$, and studies on the effect of holding time on the purity and morphology of $\mathrm{MgSiN}_{2}$ are lacking.

In this study, single-phase $\mathrm{MgSiN}_{2}$ powders were successfully prepared by nitridation of the $\mathrm{Mg}$-Si system, and the effects of temperature and holding time on the purity and morphology of the products were also investigated. The purpose of this study was to obtain the desired products at low temperature, as well as to shorten the required time of nitridation. We believe that this discovery can pave the way for preparing $\mathrm{MgSiN}_{2}$ with low energy consumption.

\section{Materials and Methods}

Mg ( $>99$ wt\% purity, Aldrich Reagent Co. Ltd.) and Si (99.99 wt\% purity, 300 mesh, Adamas Reagent Co. Ltd.) were used as starting materials to synthesize $\mathrm{MgSiN}_{2}$. The raw $\mathrm{Mg}$ and $\mathrm{Si}$ materials were mixed and grinded in an agate mortar with a mole ratio of 2:1. Due to the evaporation of $\mathrm{Mg}$, the $\mathrm{Mg} / \mathrm{Si}$ value deviated from the stoichiometric ratio, a large amount of $\mathrm{Mg}$ was consumed. Subsequently, the mixed powders were placed in an alumina crucible, which was covered with a carbon cloth; the mixtures were also covered with a carbon cloth 
to prevent $\mathrm{Mg}$ from evaporating. Then, the crucible containing the mixed powders was sealed and placed in the middle part of a high temperature resistance furnace. After vacuum was pumped, the furnace was filled with nitrogen at a flow rate of $200 \mathrm{~mL} \cdot \mathrm{min}^{-1}$, and heated at temperatures between $500^{\circ} \mathrm{C}$ and $1450^{\circ} \mathrm{C}$ for different holding time. The heating rate was $5^{\circ} \mathrm{C} \cdot \mathrm{min}^{-1}$ for all samples.

After thermal treatment, the products were ground using a mortar and pestle before testing. The phase composition of the samples was examined by using an X-ray powder diffraction (XRD) analyzer (D8 ADVANCE A25, Bruker Corporation, Germany) with $\mathrm{Cu} \mathrm{K} \alpha$ radiation, operating at $40 \mathrm{kV}$ and $40 \mathrm{~mA}$. The particle sizes and morphologies of the synthesized powders were determined using scanning electron microscopy (SEM) (Nova Nano SEM 450, FEI Corporation, America).

\section{Results and Discussion}

The XRD patterns of the products synthesized within the temperature range of $500^{\circ} \mathrm{C}-1450^{\circ} \mathrm{C}$ starting from $\mathrm{Mg}$ and $\mathrm{Si}$ are shown in Figure 1 . At $500^{\circ} \mathrm{C}, \mathrm{Mg}$ and $\mathrm{Si}$ did not react efficiently and only a little amount of $\mathrm{Mg}_{2} \mathrm{Si}$ was formed. As the temperature increased, $\mathrm{Mg}$ and $\mathrm{Si}$ reacted to generate a large amount of $\mathrm{Mg}_{2} \mathrm{Si}$ at $750^{\circ} \mathrm{C}$, although some unreacted Si remained. At $900^{\circ} \mathrm{C} \mathrm{MgSiN}_{2}$ formed; it is possible that $\mathrm{Mg}_{2} \mathrm{Si}$ reacted with $\mathrm{N}_{2}$ to afford $\mathrm{MgSiN}_{2}$ and $\mathrm{Mg}_{3} \mathrm{~N}_{2}$. The formation of $\mathrm{Mg}_{2} \mathrm{Si}$ from $\mathrm{Mg}$ and Si probably occurred as follows:

$$
2 \mathrm{Mg}+\mathrm{Si} \rightarrow \mathrm{Mg}_{2} \mathrm{Si}
$$

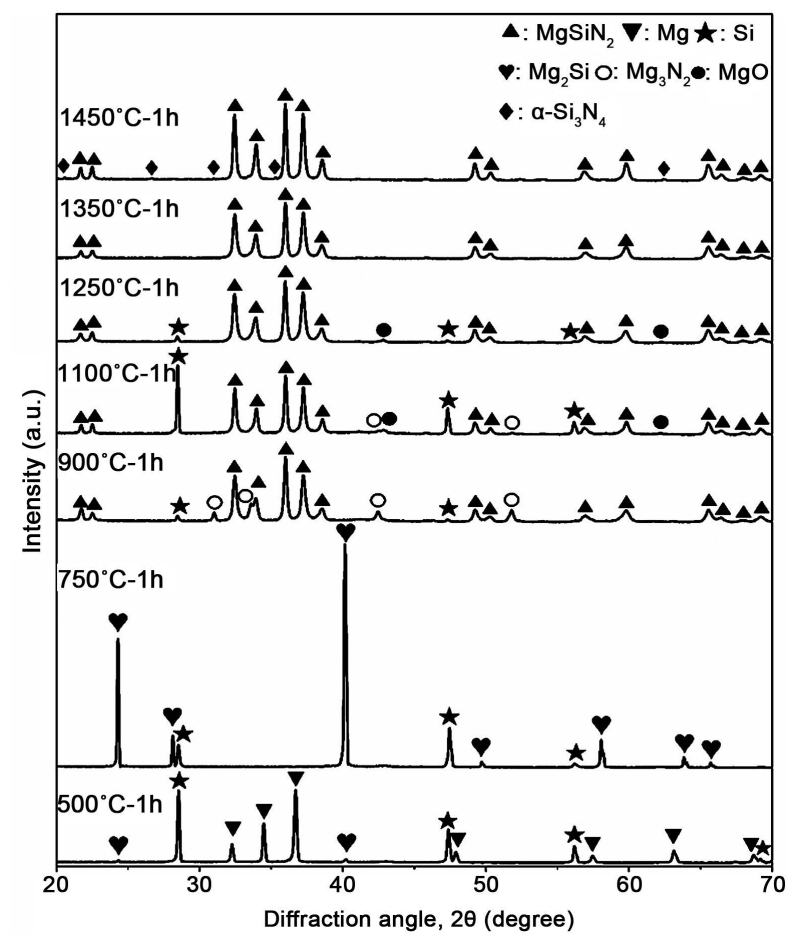

Figure 1. XRD patterns of the products synthesized at different temperatures. 
The reaction between $\mathrm{Mg}_{2} \mathrm{Si}$ and $\mathrm{N}_{2}$ may take place as follows:

$$
3 \mathrm{Mg}_{2} \mathrm{Si}+4 \mathrm{~N}_{2} \rightarrow 3 \mathrm{MgSiN}_{2}+\mathrm{Mg}_{3} \mathrm{~N}_{2}
$$

A large amount of $\mathrm{Si}$ was present at $1100^{\circ} \mathrm{C}$; given that the melting point of $\mathrm{Mg}_{2} \mathrm{Si}$ is $1102^{\circ} \mathrm{C}$, it can be speculated that the decomposition of $\mathrm{Mg}_{2} \mathrm{Si}$ occurred at this temperature. As the temperature continued to rise, a single-phase $\mathrm{MgSiN}_{2}$ appeared at $1350^{\circ} \mathrm{C}$. The high temperature allowed the starting materials to react completely to generate the nitride, causing the evaporation of the $\mathrm{MgO}$ present in the reaction mixture as well as the decomposition of the $\mathrm{Mg}_{3} \mathrm{~N}_{2}$ product into $\mathrm{N}_{2}$ and $\mathrm{Mg}(\mathrm{g})$ as follows:

$$
\mathrm{Mg}_{3} \mathrm{~N}_{2} \rightarrow 3 \mathrm{Mg}(\mathrm{g})+\mathrm{N}_{2}(\mathrm{~g})
$$

The formation of $\mathrm{MgO}$ may be due to the presence of oxygen impurities in the raw material, oxygen pickup during mixing, and oxygen in the $\mathrm{N}_{2}$ atmosphere; thus, the oxygen reacts with $\mathrm{Mg}$ or $\mathrm{Mg}_{3} \mathrm{~N}_{2}$ to form $\mathrm{MgO}$. At $1450^{\circ} \mathrm{C}, \mathrm{MgSiN}_{2}$ decomposed to give rise to $\mathrm{Si}_{3} \mathrm{~N}_{4}$. When the experiments were conducted at $1450^{\circ} \mathrm{C}$ for $3 \mathrm{~h}$, the content of $\mathrm{Si}_{3} \mathrm{~N}_{4}$ increased. Figure 2 shows the SEM images and EDS analysis results of the products synthesized at $1450^{\circ} \mathrm{C}$ after holding for (a) and (b) $1 \mathrm{~h}$, (c) and (d) $3 \mathrm{~h}$. The EDS results show that the hexagonal prism-like crystals of Figure 2(a) and Figure $2(\mathrm{c})$ are $\mathrm{Si}_{3} \mathrm{~N}_{4}$. Pt exists because the samples were plated with platinum before testing samples for EDS, the Mg exists because a small amount of $\mathrm{MgSiN}_{2}$ is attached to the surface of the $\mathrm{Si}_{3} \mathrm{~N}_{4}$ in the test area. Upon increasing of the holding time, the crystal size of $\mathrm{MgSiN}_{2}$ became larger. Previous studies described that the thermal stability of $\mathrm{MgSiN}_{2}$ is up to $1400^{\circ} \mathrm{C}[32]$. Compared with combustion synthesis method, due to the combustion temperature greatly exceeds the melting point of $\mathrm{Mg}$ and maintained for

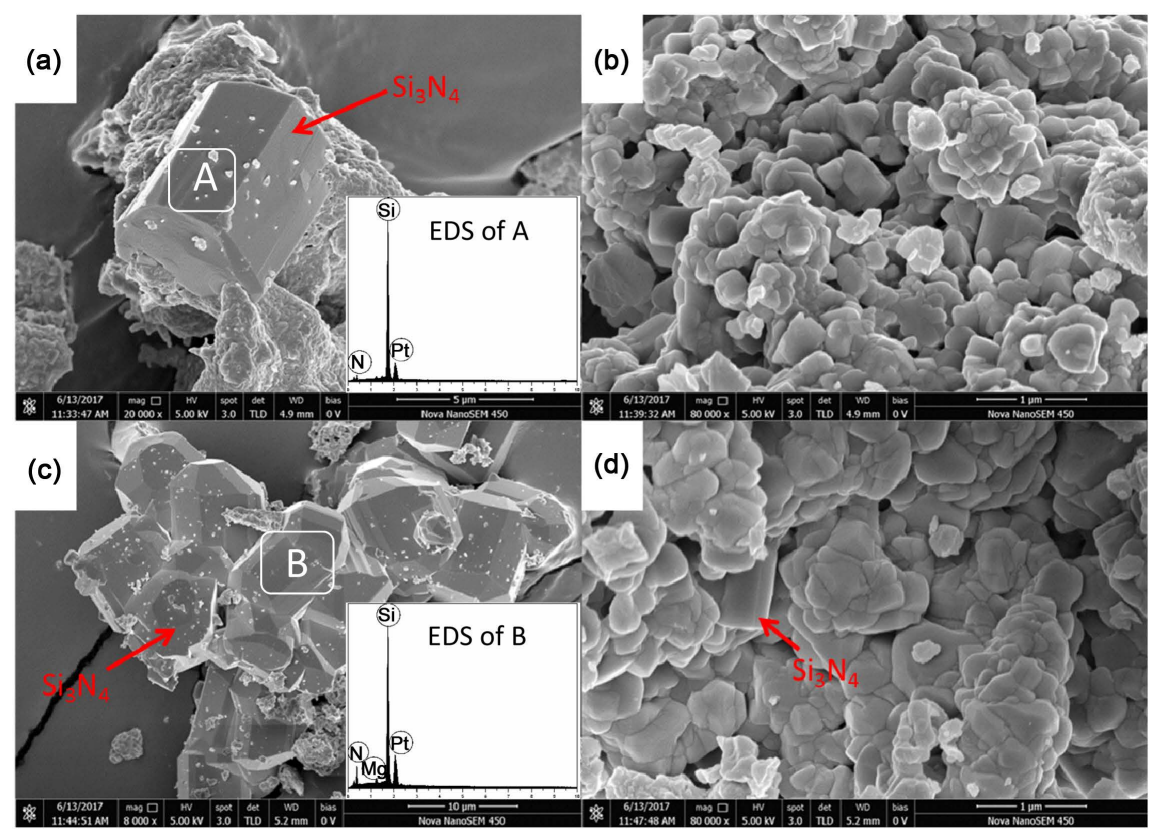

Figure 2. SEM images and EDS analysis results of the products synthesized at $1450^{\circ} \mathrm{C}$ after holding for (a) and (b) $1 \mathrm{~h}$; (c) and (d) $3 \mathrm{~h}$. 
a long time, resulting in a large number of evaporation of magnesium, so the product in addition to $\mathrm{MgSiN}_{2}$ also appeared in $\mathrm{Si}, \mathrm{MgO}$ and not identified phases [11]. Oxygen impurities will reduce the thermal conductivity of the product, but the $\mathrm{MgO}$ can be washed off by acid washing [29]. As of now, there has been no literature to report that $\mathrm{Mg}$ and $\mathrm{Si}$ can be synthesized by combustion synthesis to obtain a single phase of the $\mathrm{MgSiN}_{2}$ powder.

Figure 3 shows the XRD patterns of the products synthesized at $1350^{\circ} \mathrm{C}$ for different holding time. It was found that the powder of the middle part of the sample was measured and the result was single phase $\mathrm{MgSiN}_{2}$. Although after $8 \mathrm{~h}$ some black powders appeared around the product that were completely separated from it. Figure 4 shows the XRD pattern of these black powders, which suggested the presence of some $\mathrm{Si}_{3} \mathrm{~N}_{4}$ and $\mathrm{Si}$ impurities in addition to $\mathrm{MgSiN}_{2}$. This indicates that not only the decomposition of $\mathrm{MgSiN}_{2}$ into $\mathrm{Mg}$ and $\mathrm{Si}_{3} \mathrm{~N}_{4}$ occurred owing to the long reaction time, but also $\mathrm{Si}_{3} \mathrm{~N}_{4}$ decomposed according to the following reaction [32]:

$$
3 \operatorname{MgSiN}_{2}(\mathrm{~s}) \rightarrow 3 \mathrm{Mg}(\mathrm{g})+3 \mathrm{x} \mathrm{Si}(\mathrm{l})+(1-\mathrm{x}) \mathrm{Si}_{3} \mathrm{~N}_{4}(\mathrm{~s})+(1+2 \mathrm{x}) \mathrm{N}_{2}(\mathrm{~g})
$$

Furthermore, a small amount of white fibrous powder was observed around the crucible upon holding for a long time; although the amount was too small to be tested, it most likely consisted of $\mathrm{MgO}$. The oxygen in the gas atmosphere reacted with $\mathrm{Mg}$ or $\mathrm{Mg}_{3} \mathrm{~N}_{2}$ to form $\mathrm{MgO}$.

We also attempted to obtain $\mathrm{MgSiN}_{2}$ at low temperature $\left(1250^{\circ} \mathrm{C}\right)$. Therefore, different amounts of urea were added to the raw materials to promote nitridation and reduce the impurities, but this did not lead to major improvements.

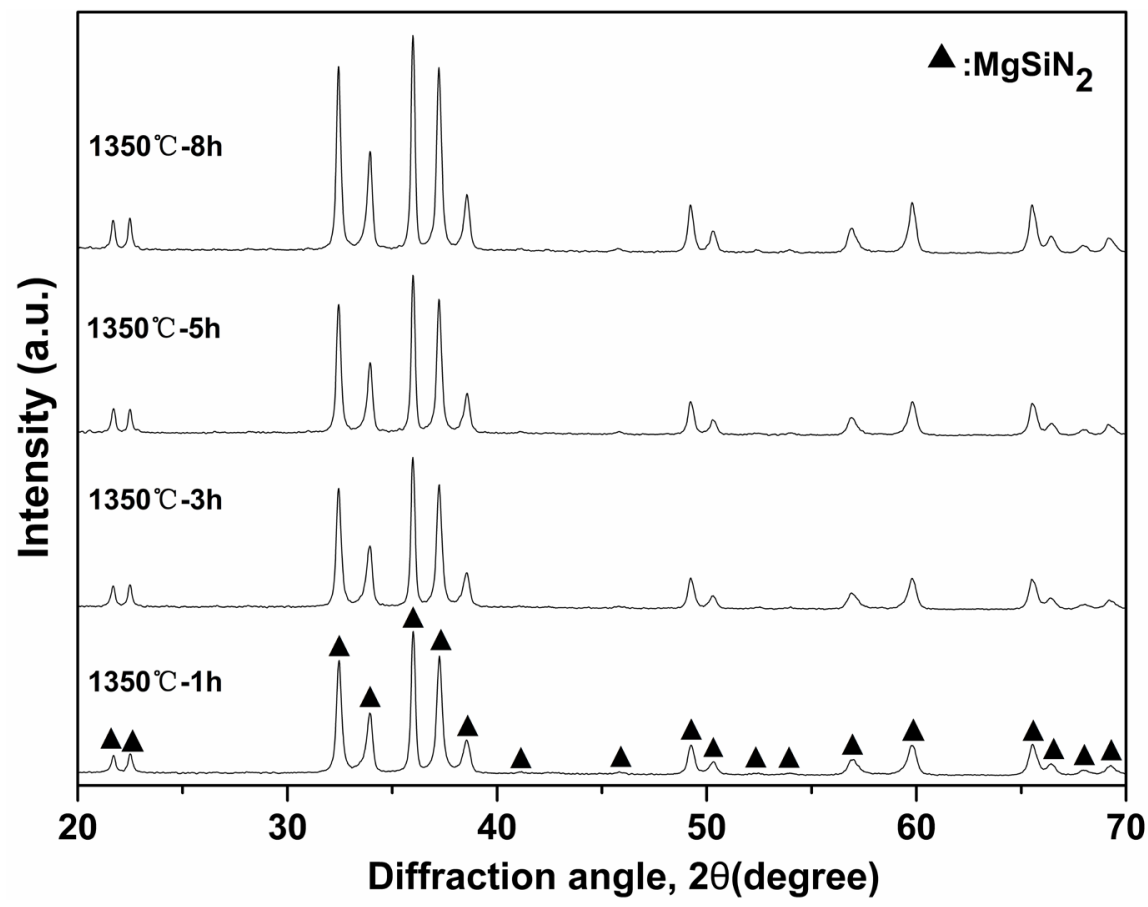

Figure 3. XRD patterns of the products synthesized at $1350^{\circ} \mathrm{C}$ after holding for different holding time. 


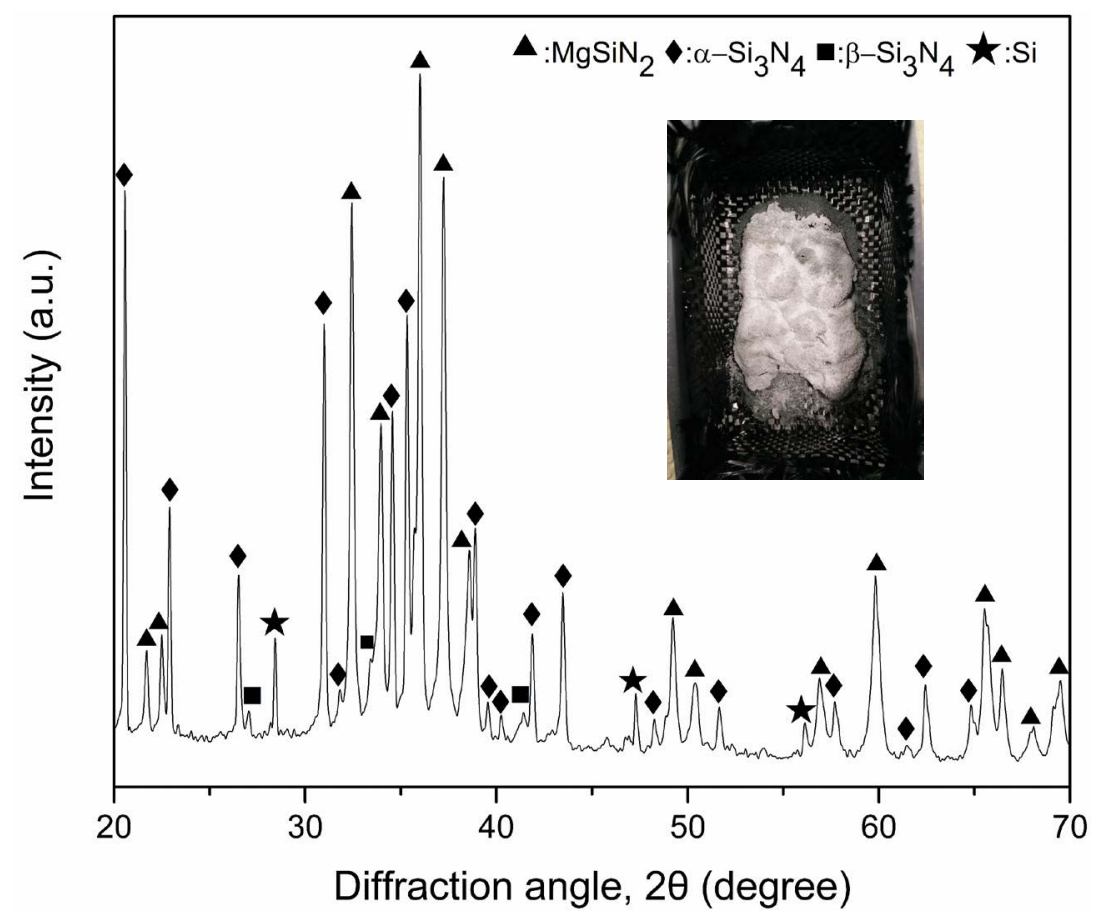

Figure 4. XRD pattern of the black powders surrounding the synthesized white products at $1350^{\circ} \mathrm{C}$ after holding for $8 \mathrm{~h}$.

Although the urea could reduce the Si content and produce smaller particles, a small amount of $\mathrm{Si}$ and $\mathrm{MgO}$ were found to be still present. Thus, we decided to increase the holding time in order to obtain single-phase $\mathrm{MgSiN}_{2}$ and influence the morphology of the products. Figure 5 shows the XRD patterns of the products synthesized at $1250^{\circ} \mathrm{C}$ for different holding time. As the holding time increased, the Si impurity gradually decreased, and single-phase $\mathrm{MgSiN}_{2}$ was obtained when the holding time was up to $11 \mathrm{~h}$. By increasing the holding time, $\mathrm{Si}$ could be removed at low temperatures. Figure 6 shows the SEM images and EDS patterns of the product synthesized at $1250^{\circ} \mathrm{C}$ after holding for $5 \mathrm{~h}$. The crystals mainly grew into two types, i.e., lump and columnar. The EDS results of the sample are shown in the lower left corner of Figure 6, confirms that both types of products are $\mathrm{MgSiN}_{2}$. With the increase of the holding time, the grain size of the lumpy shaped crystals became larger. Figure 7 shows the SEM images of the products synthesized at $1250^{\circ} \mathrm{C}$ for (a) $8 \mathrm{~h}$, (b) $1 \mathrm{~h}$ and at $1350^{\circ} \mathrm{C}$ for (c) $1 \mathrm{~h}$, while the diagrams on the right are partial enlargements of the left graphs. Figure 7 (b) shows that the grains did not grow due to the low temperature and short time. As shown in Figure 7(a), the grains gradually gathered and grew along the original column with the increase of the holding time. Form Figure $7(c)$, it is clear that when the temperature was high enough for the reaction to go to completion, the grains gradually sintered into blocks. In summary, with the increase of temperature and holding time, the particles gradually became larger; however, the temperature had a greater effect on the particle size than the holding time. 


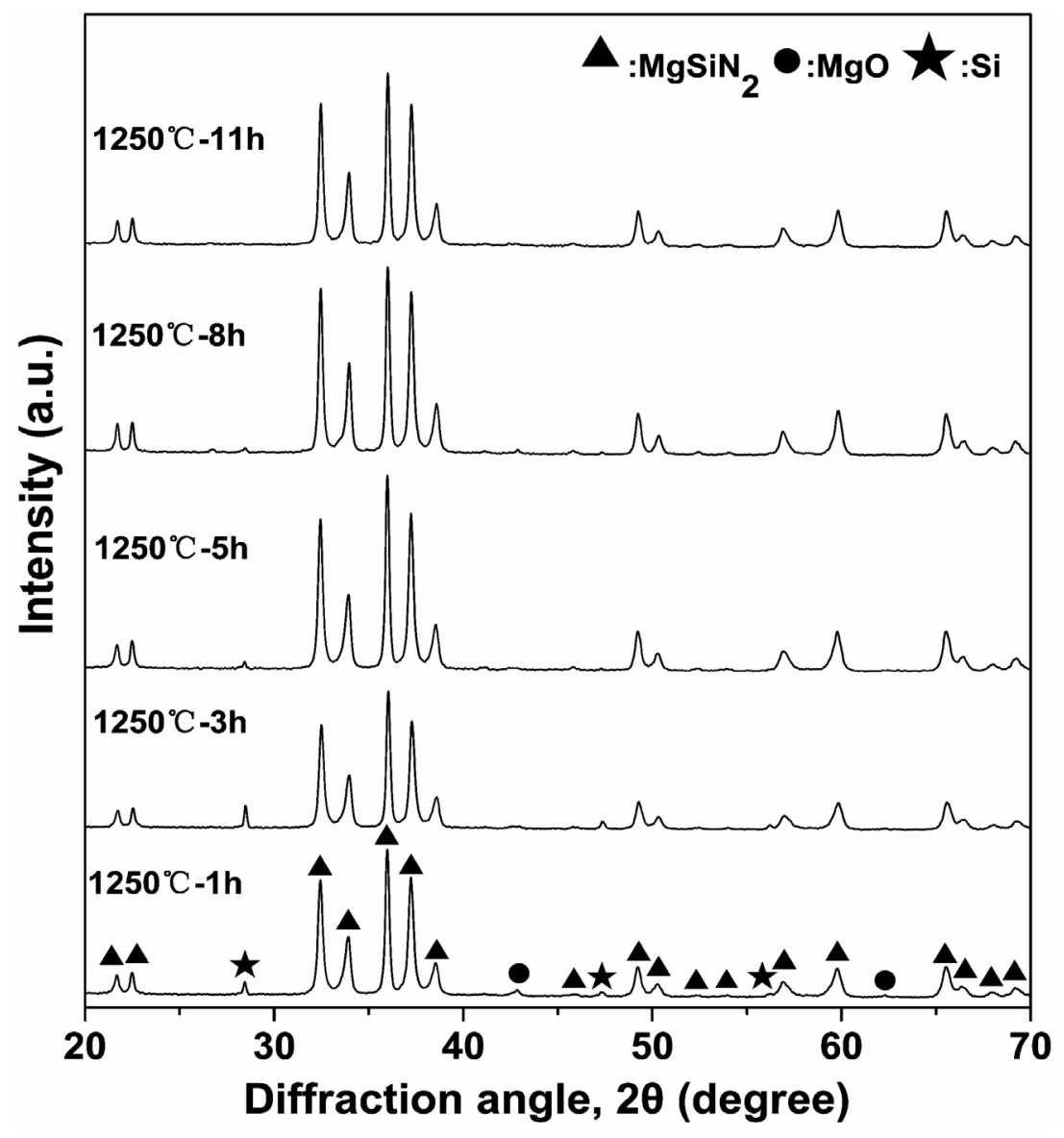

Figure 5. XRD patterns of the products synthesized at $1250^{\circ} \mathrm{C}$ for different holding times.

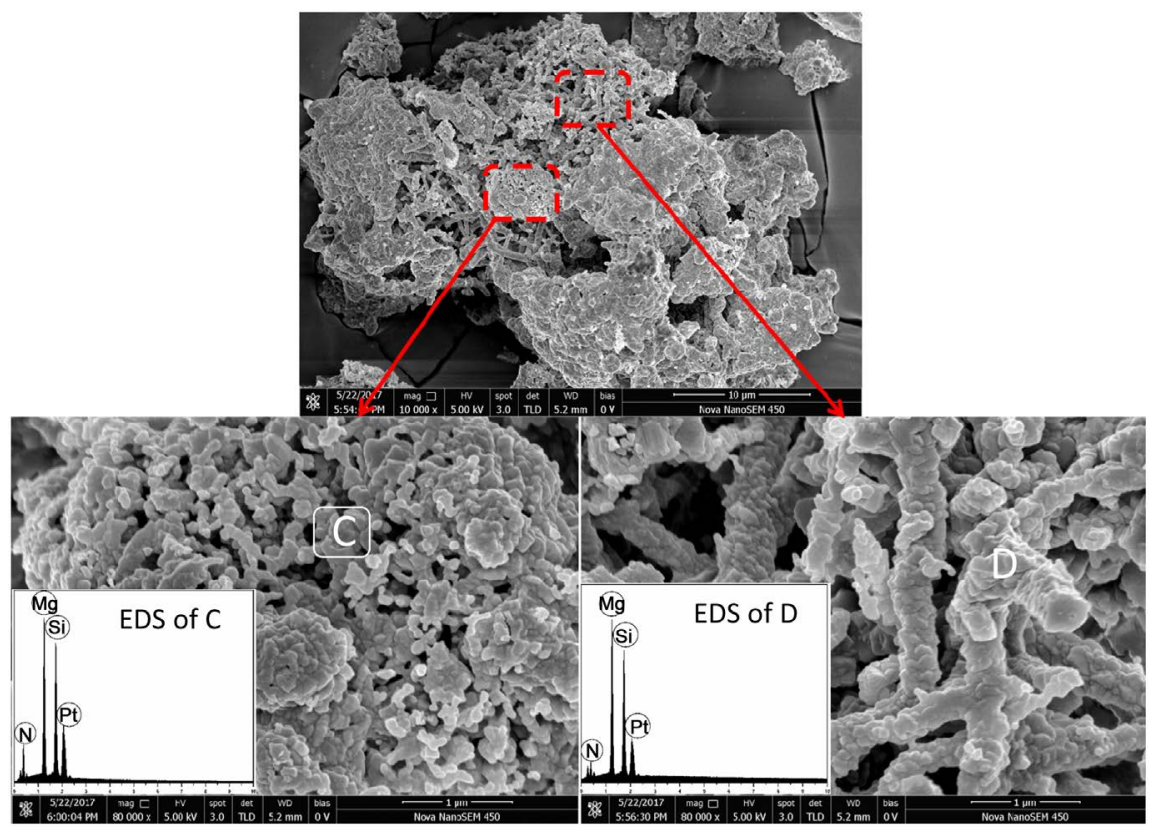

Figure 6. SEM images and EDS patterns of the product synthesized at $1250^{\circ} \mathrm{C}$ after holding for $5 \mathrm{~h}$. 


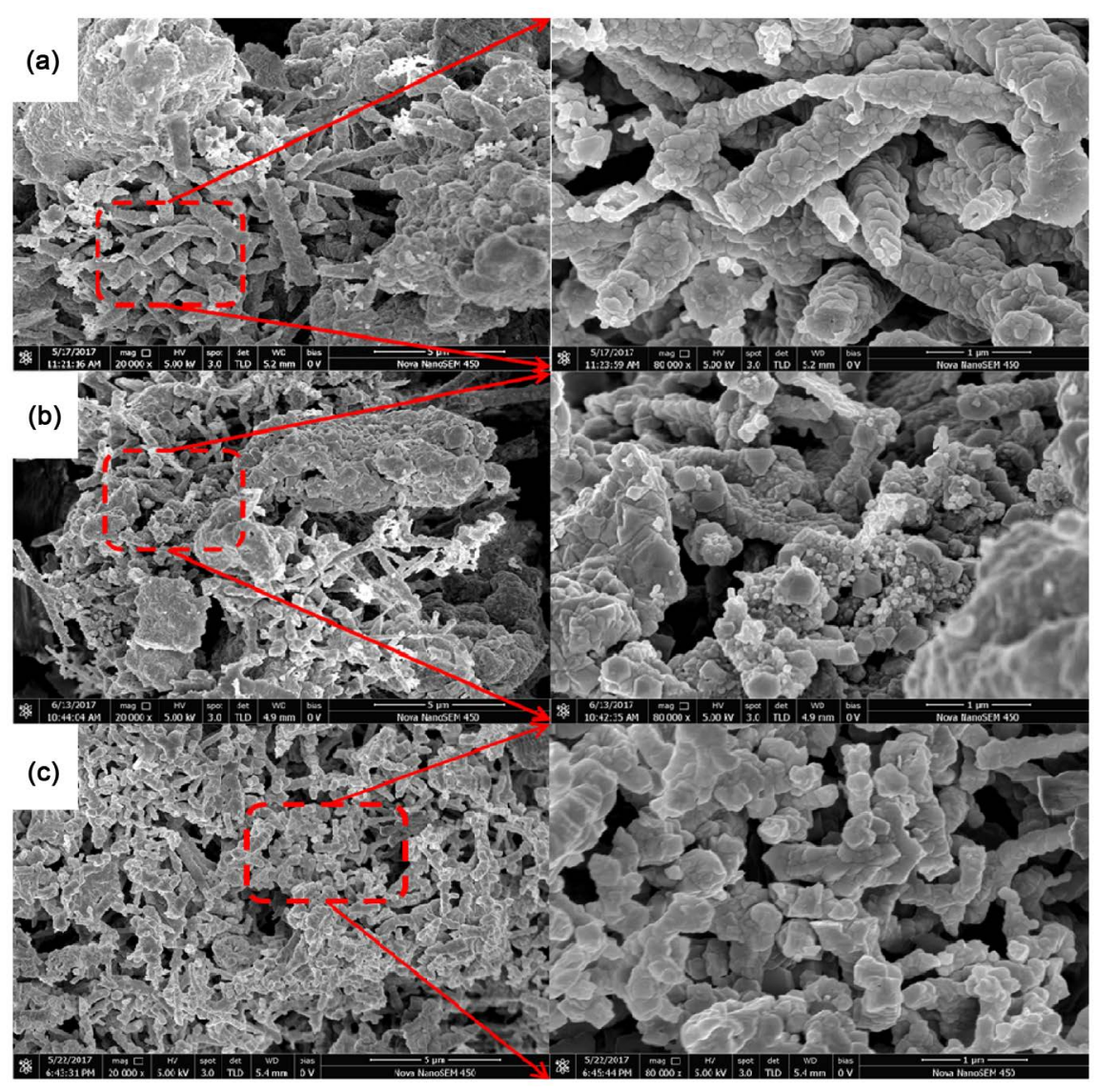

Figure 7. SEM images of the products synthesized at $1250^{\circ} \mathrm{C}$ after holding for (a) $8 \mathrm{~h}$; (b) $1 \mathrm{~h}$ and at $1350^{\circ} \mathrm{C}$ for (c) $1 \mathrm{~h}$.

From a large number of SEM photographs, it was evident that upon increasing of the holding time, the products with a columnar morphology gradually decreased at $1350^{\circ} \mathrm{C}$. At $1250^{\circ} \mathrm{C}$ the products with a columnar morphology mostly appeared in a hollow, which may be caused by the evaporation of $\mathrm{Mg}$. The formation of these voids also provides new space for the production of $\mathrm{MgSiN}_{2}$. Within a void, $\mathrm{Mg}$ and Si vapors may have a certain concentration gradient leading to the growth of many columns. Another form of growth is also shown in Figure 8. Figure 8(a) shows that the products with columnar morphologies grew on a solid surface. The columnar formation may be due to a larger temperature gradient on the solid surface. The farther away from the solid, the lower the temperature, the smaller the activity of the gas, and the easier it is to absord the reaction gas; thus, $\mathrm{MgSiN}_{2}$ easily grows along the tip. As shown in Figure 8(b), it is possible that $\mathrm{Mg}$ and Si continued to grow along the inner surface of the cavity because of the relatively strong adsorption of nitrogen on the surface of $\mathrm{Mg}$ and $\mathrm{Si}$. The schematic illustration of the mechanism of particle formation on solid surfaces and voids is shown in Figure 9. As the temperature increased, the reactants gradually reacted to form massive amounts of $\mathrm{MgSiN}_{2}$. However, the temperature was much higher than the boiling point of $\mathrm{Mg}$, so a large amount of $\mathrm{Mg}$ and a small amount of $\mathrm{Si}$ evaporated. The evaporation of 


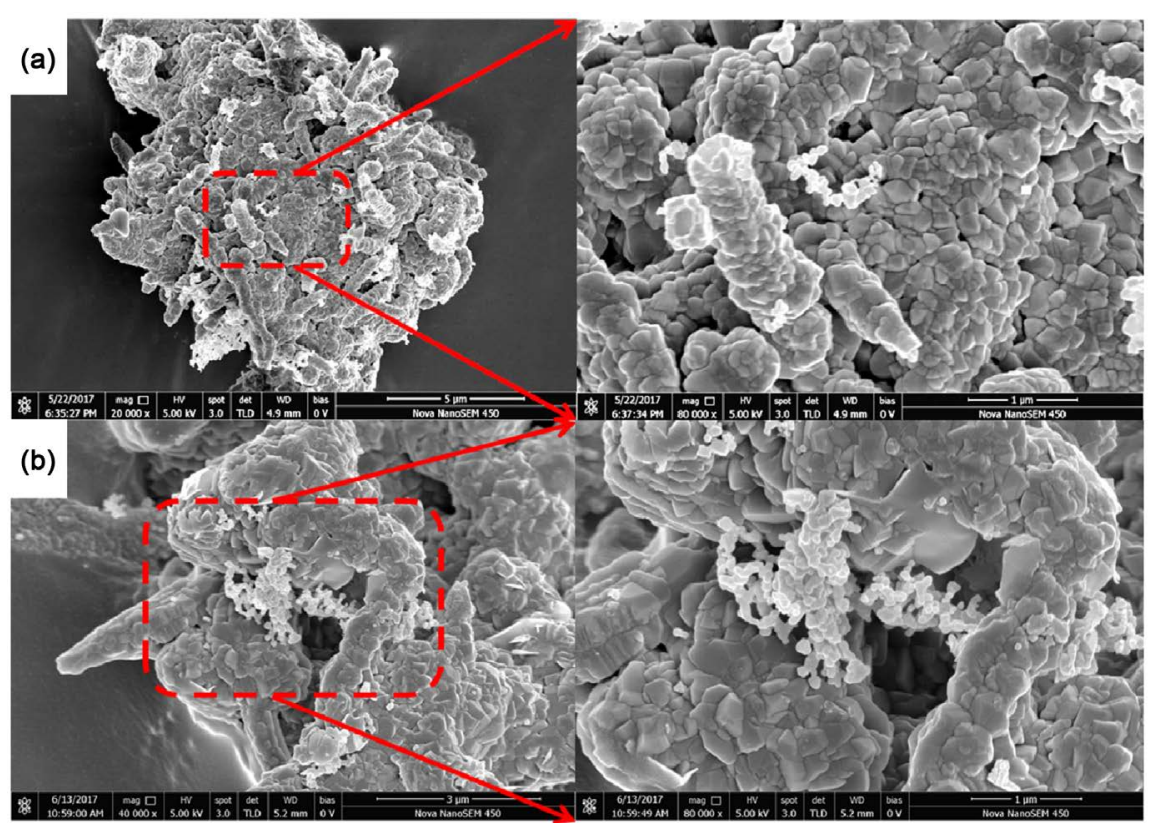

Figure 8. SEM images of the products synthesized at $1250^{\circ} \mathrm{C}$ after holding for $8 \mathrm{~h}$.

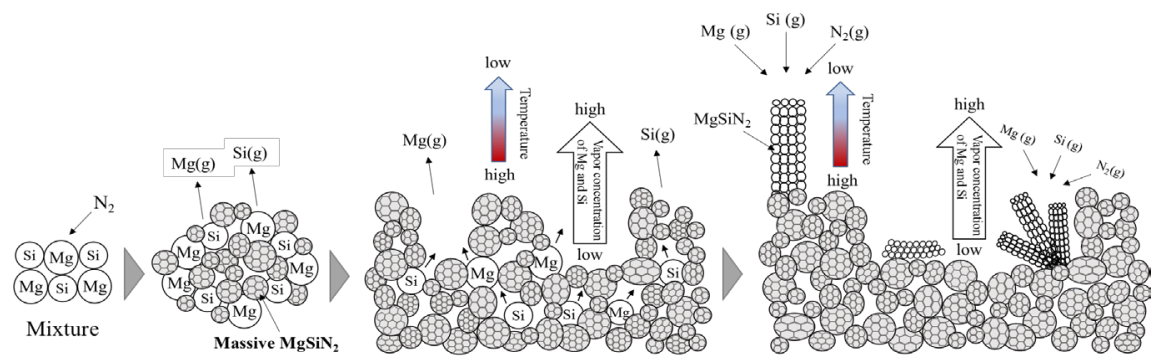

Figure 9. Schematic illustration of the mechanism of particle formation within solid surfaces and voids.

$\mathrm{Mg}$ and Si resulted in the formation of many voids in the blocky product. The higher is the temperature, the greater is the gas activity, and the smaller is the gas adsorption on the surface of $\mathrm{MgSiN}_{2}$ [33]. This may be because the surface of block products possesses a certain temperature gradient. Thus, the farther away from the surface of the block product, the lower is the temperature, the more easily adsorbed is the gas; this promotes the growth of $\mathrm{MgSiN}_{2}$ on the surface of massive products along the tip. Within the voids of the bulk products, it is possible that the evaporation of $\mathrm{Mg}$ and $\mathrm{Si}$ results in a concentration gradient of $\mathrm{Mg}$ and $\mathrm{Si}$ vapors in the void, resulting in the columnar growth of $\mathrm{MgSiN}_{2}$. However, it is possible that some of the surfaces of $\mathrm{Mg}$ and $\mathrm{Si}$ still have adsorption properties, which can absord $\mathrm{N}_{2}, \mathrm{Mg}$ and $\mathrm{Si}$ atoms, so that some $\mathrm{MgSiN}_{2}$ grows along the surface of the block products.

\section{Conclusion}

A single-phase of $\mathrm{MgSiN}_{2}$ was obtained either at $1350^{\circ} \mathrm{C}$ for $1 \mathrm{~h}$ or at $1250^{\circ} \mathrm{C}$ for $11 \mathrm{~h}$ using $\mathrm{Mg} / \mathrm{Si}$ as starting materials with a mole ratio of 2:1 under a $\mathrm{N}_{2}$ at- 
mosphere. Although this product could be obtained at low temperature $\left(1250^{\circ} \mathrm{C}\right)$, the holding time required was too long and the process involved great energy consumption. Thus, the most economical temperature was $1350^{\circ} \mathrm{C}$. With the increase of the holding time, the grain size of lumpy shaped crystals became larger, and the size of grains with a columnar morphology also increased becoming more uniform. As the temperature increased, the products with a columnar morphology gradually decreased. Moreover, when the temperature reached $1450^{\circ} \mathrm{C}$, the decomposition of $\mathrm{MgSiN}_{2}$ occurred, and $\mathrm{Si}_{3} \mathrm{~N}_{4}$ particles could be clearly seen in the SEM images. This simple and energy-efficient method for the preparation of $\mathrm{MgSiN}_{2}$ further promotes its use as a fundamental material for electronic equipment to achieve an enhanced thermal conductivity.

\section{Acknowledgements}

We thank the Life Science Research Core Services of Northwest A \& F University for providing scanning electron microscope. This work was supported by the special funds for basic research projects of Northwest Agriculture and Forestry University (NO. Z109021534) and International Science and Technology Cooperative Seed Fund Project of Northwest Agriculture and Forestry University (NO. A213021607).

\section{References}

[1] Yi, X.M., Suzuki, S., Liu, X.Z., Guo, R. and Akiyama, T. (2017) Combustion Synthesis of $\beta$-SiAlON Using 3D Ball Milling. Materials Science Forum, 898, 1717-1723. https://doi.org/10.4028/www.scientific.net/MSF.898.1717

[2] Yi, X.M., Guo, R., Liu, X.Z., Zhang, W.G. and Yan, F.X. (2016) Spark Plasma Sintering of Combustion-Synthesized Beta-SiAlON Powders. Ceramics International, 42, 6707-6712. https://doi.org/10.1016/j.ceramint.2016.01.038

[3] Hiranaka, A., Yi, X.M., Saito, G., Niu, J. and Akiyama, T. (2017) Effects of Al Particle Size and Nitrogen Pressure on AlN Combustion Synthesis. Ceramics International, 43, 9872-9876. https://doi.org/10.1016/j.ceramint.2017.04.170

[4] Guo, W.M., Wu, L.X., Ma, T., You, Y. and Lin, H.T. (2016) Rapid Fabrication of $\mathrm{Si}_{3} \mathrm{~N}_{4}$ Ceramics by Reaction-Bonding and Pressureless Sintering. Journal of the European Ceramic Society, 36, 3919-3924. https://doi.org/10.1016/j.jeurceramsoc.2016.06.007

[5] Niu, J., Harada, K., Suzuki, S., Nakatsugawa, I., Okinaka, N. and Akiyama, T. (2014) Fabrication of Mixed $\alpha / \beta$-SiAlON Powders via Salt-Assisted Combustion Synthesis. Journal of Alloys and Compounds, 604, 260-265. https://doi.org/10.1016/j.jallcom.2014.03.145

[6] Yi, X.M., Niu, J., Nakamura, T. and Akiyama, T. (2013) Reaction Mechanism for Combustion Synthesis of Beta-SiAlON by Using $\mathrm{Si}, \mathrm{Al}$, and $\mathrm{SiO}_{2}$ as Raw Materials. Journal of Alloys and Compounds, 561, 1-4. https://doi.org/10.1016/j.jallcom.2013.01.170

[7] Yi, X.M. and Akiyama, T. (2010) Mechanical-Activated, Combustion Synthesis of $\beta$ SiAlON. Journal of Alloys and Compounds, 495, 144-148. https://doi.org/10.1016/j.jallcom.2010.01.105

[8] Lenčéš, Z., Hirao, K., Kanzaki, S., Hoffmann, M.J. and Šajgalík, P. (2004) Reaction 
Sintering of Fluorine-Doped $\mathrm{MgSiN}_{2}$. Journal of the European Ceramic Society, 24, 3367-3375. https://doi.org/10.1016/j.jeurceramsoc.2003.10.022

[9] Khajelakzay, M., Bakhshi, S.R. and Borhani, G.H. (2015) Synthesis of Magnesium Silicon Nitride Nanopowder by Employing Two-Step Method. Advances in Applied Ceramics, 114, 321-325. https://doi.org/10.1179/1743676115Y.0000000005

[10] Peng, L., Xu, L.Q., Ju, Z.C., Zhang, J., Yang, J. and Qian, Y.T. (2007) Large-Scale Synthesis of Magnesium Silicon Nitride Powders at Low Temperature. Journal of American Ceramic Society, 91, 333-336. https://doi.org/10.1111/j.1551-2916.2007.02141.x

[11] Peng, G.H., Jiang, G.J., Zhuang, H.R. and Li, W.L. (2005) A Novel Route for Preparing $\mathrm{MgSiN}_{2}$ Powder by Combustion Synthesis. Materials Science and Engineering: $A$, 397, 65-68. https://doi.org/10.1016/j.msea.2005.01.047

[12] Tanaka, S., Itatani, K., Uchida, H., Aizawa, M., Davies, I.J., Suemasu, H., Nozue, A. and Okada, I. (2002) The Effect of Rare-Earth Oxide Addition on the Hot-Pressing of Magnesium Silicon Nitride. Journal of the European Ceramic Society, 22, 777783. https://doi.org/10.1016/S0955-2219(01)00380-6

[13] Itatani, K., Davies, I.J., Kuwano, H. and Aizawa, M. (2002) Sinterability of Magnesium Silicon Nitride Powder with Yttrium Oxide Addition Coated Using the Homogeneous Precipitation Method. Journal of Materials Science, 37, 737-744. https://doi.org/10.1023/A:1013835713676

[14] Chen, B. (2012) Preparation of Boride, Carbide and Nitride Micro/Nanocrystal by Sodium Sulfide Assisted Low Temperature Initiation. PhD Thesis, Shandong University, Jinan. (In Chinese)

[15] Peng, G.H., Lu, F.Q., Liang, Z.H., Liu, X. and Li, W.L. (2010) Study on the Synthesis of $\mathrm{MgSiN}_{2}$ by a Powder Combustion Reaction Process. Powder Metal Technologies, 28, 178-182. (In Chinese)

[16] Jiang, G.J., Xu, J.Y., Shen, H., Zhang, Y., Peng, G.H., Zhuang, H.R., Li, W.L., Xu, S.Y. and Mao, Y.J. (2010) Fabrication of Silicon Nitride Ceramics with Magnesium Silicon Nitride and Yttrium Oxide as Sintering Additives. 1st Annual Meeting on Testing and Evaluation of Inorganic Materials, Nanchang, 28-30 April 2010, 235237.

[17] Liang, Z.H., Li, J., Gui, L.C., Peng, G.H., Zhang, Z. and Jiang, G.J. (2013) The Role of $\mathrm{MgSiN}_{2}$ during the Sintering Process of Silicon Nitride Ceramic. Ceramics International, 39, 3817-3822. https://doi.org/10.1016/j.ceramint.2012.10.222

[18] Liang, Z.H., Zhang, H.L., Gui, L.C., Li, J., Peng, G.H. and Jiang, G.J. (2013) Effects of Whisker-Like $\beta$-Si ${ }_{3} \mathrm{~N}_{4}$ Seeds on Phase Transformation and Mechanical Properties of $\alpha / \beta \mathrm{Si}_{3} \mathrm{~N}_{4}$ Composites using $\mathrm{MgSiN}_{2}$ as Additives. Ceramics International, 39, 2743-2751. https://doi.org/10.1016/j.ceramint.2012.09.041

[19] Peng, G.H., Jiang, G.J., Zhuang, H.R., Li, W.L. and Xu, S.Y. (2005) Fabrication of $\beta$-Si ${ }_{3} \mathrm{~N}_{4}$ Whiskers by Combustion Synthesis with $\mathrm{MgSiN}_{2}$ as Additives. Materials Research Bulletin, 40, 2139-2143. https://doi.org/10.1016/j.materresbull.2005.07.002

[20] Peng, G.H., Zhang, H.L., Li, J., Liang, Z.H., Gui, L.C. and Jiang, G.J. (2012) A Translucent and Hard $\alpha / \beta \mathrm{Si}_{3} \mathrm{~N}_{4}$ Composite Hot-Pressed at Low Temperature with an $\mathrm{MgSiN}_{2}$ Additive. Scripta Materialia, 67, 1011-1014. https://doi.org/10.1016/j.scriptamat.2012.09.017

[21] Kulshreshtha, C., Kwak, J.H., Park, Y.J. and Sohn, K.S. (2009) Photoluminescent and Decay Behaviors of $\mathrm{Mn}^{2+}$ and $\mathrm{Ce}^{3+}$ Coactivated $\mathrm{MgSiN}_{2}$ Phosphors for Use in Light-Emitting-Diode Applications. Optics Letters, 34, 794-796.

https://doi.org/10.1364/OL.34.000794 
[22] Duan, C.C., Delsing, A.A. and Hintzen, H.B. (2009) Red Emission from $\mathrm{Mn}^{2+}$ on a Tetrahedral Site in $\mathrm{MgSiN}_{2}$. The Journal of Bone and Joint Surgery. American Volume, 56, 1733-1734.

[23] Hirao, K., Hayashi, H., Itatani, K. and Yamauchi, Y. (2002) Effect of $\mathrm{MgSiN}_{2}$ Addition on Microstructure and Thermal Conductivity of Silicon Nitride Ceramics. Key Engineering Materials, 206-213, 1021-1024.

[24] Michálková, M., Lenčéš, Z., Michálek, M., Kocher, P., Kuebler, J. and Šajgalík, P. (2013) Improvement of Electrical Conductivity of Silicon Nitride/Carbon NanoFibers Composite using Magnesium Silicon Nitride and Ytterbium Oxide as Sintering Additives. Journal of the European Ceramic Society, 33, 2429-2434. https://doi.org/10.1016/j.jeurceramsoc.2013.04.037

[25] Zhu, X.W. (2008) Effect of $\mathrm{MgSiN}_{2}$ Addition on Gas Pressure Sintering and Thermal Conductivity of Silicon Nitride with $\mathrm{Y}_{2} \mathrm{O}_{3}$. Journal of the Ceramic Society of Japan, 116, 706-711. https://doi.org/10.2109/jcersj2.116.706

[26] Uchida, H., Itatani, K., Aizawa, M., Howell, F.S. and Kishioka, A. (1997) Synthesis of Magnesium Silicon Nitride by the Nitridation of Powders in the Magnesium-Silicon System. Journal of the Ceramic Society of Japan, 105, 934-939. https://doi.org/10.2109/jcersj.105.934

[27] Bruls, R.J., Hintzen, H.T. and Metselaar, R. (1999) Preparation and Characterisation of $\mathrm{MgSiN}_{2}$ Powders. Journal of Materials Science, 34, 4519-4531. https://doi.org/10.1023/A:1004645407523

[28] Lences, Z., Hirao, K., Yamauchi, Y. and Kanzaki, S. (2003) Reaction Synthesis of Magnesium Silicon Nitride Powder. Journal of the American Ceramic Society, 86, 1088-1093. https://doi.org/10.1111/j.1151-2916.2003.tb03429.x

[29] Yang, J.H., Qiu, J.F. and Li, J.T. (2011) Preparation of Single-Phase Magnesium Silicon Nitride Powder by a Two-Step Process. Ceramics International, 37, 673-677. https://doi.org/10.1016/j.ceramint.2010.09.055

[30] Uchida, H., Itatani, K., Aizawa, M., Howell, F.S. and Kishioka, A. (1999) Preparation of Magnesium Silicon Nitride Powder by the Carbothermal Reduction Technique. Advanced Powder Technology, 10, 133-143. https://doi.org/10.1016/S0921-8831(08)60445-8

[31] Blair, R.G., Anderson, A. and Kaner, R.B. (2005) A Solid-State Metathesis Route to $\mathrm{MgSiN}_{2}$. Chemistry of Materials, 17, 2155-2161. https://doi.org/10.1021/cm048234v

[32] Lenčéš, Z., Pentráková, L., Hrabalová, M., Šajgalík, P. and Hirao, K. (2011) Decomposition of $\mathrm{MgSiN}_{2}$ in Nitrogen Atmosphere. Journal of the European Ceramic Society, 31, 1473-1480. https://doi.org/10.1016/j.jeurceramsoc.2011.02.023

[33] Zhang, Y.G. (2015) Research on High Performance Silicon Nitride Ceramic Powders. PhD Thesis, Zhejiang University, Hangzhou. (In Chinese) 